\title{
Effect of Zr on Structural and Dielectrical Properties of $\left(\mathrm{Ba}_{0.9} \mathrm{Mg}_{1.0}\right)\left(\mathrm{Zr}_{\mathrm{x}} \mathrm{Ti}_{1-\mathrm{x}}\right) \mathrm{O}_{3}$ Ceramics
}

\author{
Sankararao Gattu1, Venuturupalli Durga Prasadu2, Kocharlakota Venkata Ramesh ${ }^{2 *}$ \\ ${ }^{1}$ Department of Physics, MVJ College of Engineering, Bangalore, India \\ ${ }^{2}$ Department of Physics, GITAM Institute of Technology, GITAM University, Visakhapatnam, India \\ Email: ${ }^{*}$ kv ramesh5@yahoo.co.in
}

Received 12 August 2015; accepted 18 October 2015; published 21 October 2015

Copyright (C) 2015 by authors and Scientific Research Publishing Inc.

This work is licensed under the Creative Commons Attribution International License (CC BY). http://creativecommons.org/licenses/by/4.0/

(c) (i) Open Access

\begin{abstract}
Barium titanate, $\mathrm{BaTiO}_{3}$ (BTO) is the most common ferro electric material, which is used to manufacture electronic components such as multilayer capacitors, positive temperature coefficient thermistors, piezo electric transdures, and ferro electric memory. Zr doped barium magnesium titanate $\left(\mathrm{Ba}_{0.9} \mathrm{Mg}_{1.0}\right)\left(\mathrm{Zr}_{\mathrm{x}} \mathrm{Ti}_{1-\mathrm{x}}\right) \mathrm{O}_{3}$ (with $\mathrm{x}=0.10,0.20,0.40$ (BMZT 10, BMZT 20 and BMZT 40) perovskite is prepared by conventional solid state reaction method. The starting raw materials were $\mathrm{BaCO}_{3}, \mathrm{TiO}_{2}, \mathrm{MgO}$ and $\mathrm{ZrO}_{2}$. The XRD study at room temperature suggests that these have cubic and tetragonal symmetry phases. The behavior of the measured dielectric permittivity and dielectric loss with temperature and frequency reveals that the materials undergo a diffuse para-ferroelectric phase transition and are of the relaxor type. The crystal structure, surface morphology and dielectric properties of $\mathrm{Zr}$ and $\mathrm{Mg}$ doped barium titanate ceramics were investigated. $\mathrm{Zr}^{4+}{\text { and } \mathrm{Mg}^{2+}}^{2+}$ ions have entered the unit cell maintaining the perovskite structure of solid solution without the evidence of any additional phase when $\mathrm{Mg}$ content is $0.1 \mathrm{~mole} \%$ and the $\mathrm{Zr}$ content is $0.10,0.20$ and 0.40 mole $\%$.
\end{abstract}

\section{Keywords}

Lead Free Ceramics, $\mathrm{BaTiO}_{3}$, Dielectric Materials, Impedance, XRD, SEM

\section{Introduction}

Lead based ceramic has been studied more than anyone else ferroelectric because of their excellent dielectric

\footnotetext{
${ }^{*}$ Corresponding author.
}

How to cite this paper: Gattu, S., Prasadu, V.D. and Ramesh, K.V. (2015) Effect of Zr on Structural and Dielectrical Properties of $\left(\mathrm{Ba}_{0.9} \mathrm{Mg}_{1.0}\right)\left(\mathrm{Zr}_{\mathrm{x}} \mathrm{Ti}_{1-\mathrm{x}}\right) \mathrm{O}_{3}$ Ceramics. Advances in Materials Physics and Chemistry, 5, 419-425. 
properties [1]. However, the presence of lead in those materials is about $60 \%$ in weight [2], reconsidering its use in technical applications, due to its high toxicity of lead for the environment as well as for humans [3]-[7]. Barium titanate, $\mathrm{BaTiO}_{3}$ (BTO) is the most common ferro electric material, which is used to manufacture electronic components such as multilayer capacitors, positive temperature coefficient thermistors, piezo electric transducers, and ferro electric memory, because of its excellent dielectric, piezo electric and ferro electric properties [8]-[12]. Moreover, a constant effort is being made to develop new dielectric oxides [13]-[15]. The micro level structure and dielectric properties of BTO can be modified by addition of the dopants such as $\mathrm{La}^{3+}, \mathrm{Ce}^{2+}, \mathrm{Mn}^{4+}$, $\mathrm{Nb}^{5+}, \mathrm{Nd}^{3+}, \mathrm{Cr}^{3+}, \mathrm{Zr}^{4+}, \mathrm{Mg}^{2+}, \mathrm{Sr}^{2+}$ and $\mathrm{Si}^{4+}$ to occupy $\mathrm{Ba}^{2+}$ on $\mathrm{A}$ sites or $\mathrm{Ti}^{4+}$ on $\mathrm{B}$ sites to form the solid solution. Numerous works have also been carried out to confirm the doping effects of rare earth oxides on the microstructure and electrical properties of $\mathrm{BaTiO}_{3}-\mathrm{MgO}$ based system [16]-[32]. However, there are only few works concerned with the properties of the $\mathrm{MgO}$ singly doped barium titanate system. It is reported that when Ba is replaced by $\mathrm{Mg}$ in small quantities in the composition $\mathrm{Ba}\left(\mathrm{Zr}_{\mathrm{x}} \mathrm{Ti}_{1-\mathrm{x}}\right) \mathrm{O}_{3}$ the dielectric properties have been changed. But the transition temperature has been shifted towards lower temperature values. S. K. Rout et al. [33] reported that the transition temperature decreased with increase of substitution of Mg upto $<1.5$ mole\%. It has been reported that [34] with $15 \%$ Zr substitution in $\mathrm{Ba}(\mathrm{ZrTi}) \mathrm{O}_{3}(\mathrm{BZT})$ it exhibited three transitions rhombohedra to orthorhombic, orthorhombic to tetragonal and tetragonal to cubic. At room temperature, the doped material exhibits enhanced dielectric constant with further increase in $\mathrm{Zr}$ content beyond 15\%. Diffuse phase transition has been observed with the decrease in one transition temperature [35] and the material showed typical relaxor like behavior in the range 25 - 45 mole\% Zr substitution [7]. Unexpectedly the lead free ceramic shows the relaxor properties at low temperatures [3]. Several attempts have been made by researchers on these materials to shift the $\mathrm{T}_{\mathrm{c}}$ to close to room temperature. It is well known that homovalent and hetrovalent substitution for barium and titanium ions gives rise to various behaviors including the shifting of the transition temperature. This inspires to work on effect of $\mathrm{Zr}$ on structural and dielectrical properties of barium magnesium titanate $\left(\left(\mathrm{Ba}_{0.9} \mathrm{Mg}_{1.0}\right)\left(\mathrm{Zr}_{\mathrm{x}} \mathrm{Ti}_{1-\mathrm{x}}\right) \mathrm{O}_{3}\right)$ perovskite composition prepared through solid state reaction route because in this method limited formation of side products, no solvents are needed in the reaction and hence no waste disposal issues associated with the solvent need to be considered and do not require extensive purification to remove traces of solvent and impurities. The samples synthesized through solid state reaction method may be used for obtaining in bulk form with high density over other methods.

\section{Experimental}

The perovskite samples of $\mathrm{Zr}$ doped Barium Magnesium Titanate $\left(\mathrm{Ba}_{0.9} \mathrm{Mg}_{1.0}\right)\left(\mathrm{Zr}_{\mathrm{x}} \mathrm{Ti}_{1-\mathrm{x}}\right) \mathrm{O}_{3}$ (with $\mathrm{x}=0.10,0.20$, 0.40) (BMZT 10, BMZT 20 and BMZT 40) were prepared by conventional solid state reaction method. The starting raw materials were $\mathrm{BaCO}_{3}$ (Chen Chems., Chennai), $\mathrm{TiO}_{2}$ (Loba Chem., Mumbai), MgO (Chen Chems., Chennai) and $\mathrm{ZrO}_{2}$ (Loba Chem., Mumbai). All the powders were having more than 99\% purity. The powders were taken in a suitable stachiometry for $20 \mathrm{gm}$ of samples. The powders were thoroughly mixed in an agate mortar in dry and wet mixing with appropriate amount of acetone for $6 \mathrm{hr}$. After proper mixing, mixed powders were calcinated at $1300^{\circ} \mathrm{C}$ for $2 \mathrm{hr}, 1400^{\circ} \mathrm{C}$ for $2 \mathrm{hr}$ and $1500^{\circ} \mathrm{C}$ for $4 \mathrm{hr}$. A small amount polyvinyl alcohol was added to the calcinated powder for fabrication of pellets, which was burnt out during high temperature sintering. The circular disc shaped pellets were prepared by applying a uniaxial pressure of $4.5 \times 10^{6} \mathrm{~N} / \mathrm{m}^{2}$. The pellets were subsequently sintered at an optimized temperature of $1550^{\circ} \mathrm{C}$ for $5 \mathrm{hr}$. A preliminary study on compound formation and structural parameters was carried out using an X-ray diffraction (XRD) technique with an X-ray powder diffractometer. The XRD pattern of the calcinated powder was recorded at room temperature using PANAlytical X'pert pro with $\mathrm{CuK}_{a}$ radiation (1.5405 $\AA$ ) in a wide range of Bragg's angles $2 \theta\left(15 \leq 2 \theta \leq 80^{\circ}\right)$. Micro structures of sintered pellets were recorded by scanning electron microscope (SEM) (JEOM JSM-6380 LA). The pellets were then electrode with high purity air-drying silver paste and then dried at $500^{\circ} \mathrm{C}$ for $1 \mathrm{hr}$. Dielectric measurement analysis was done using Agilent E4980A Precision LCR meter with temperature (150 $573 \mathrm{~K}$ ) and frequency (20 Hz - $200 \mathrm{KHz})$.

\section{Results and Discussion}

\subsection{Structural Analysis}

Figure 1 shows the XRD pattern of the Zr doped BMZT $(0.1,0.2,0.4)$ samples. The XRD analysis provides that 


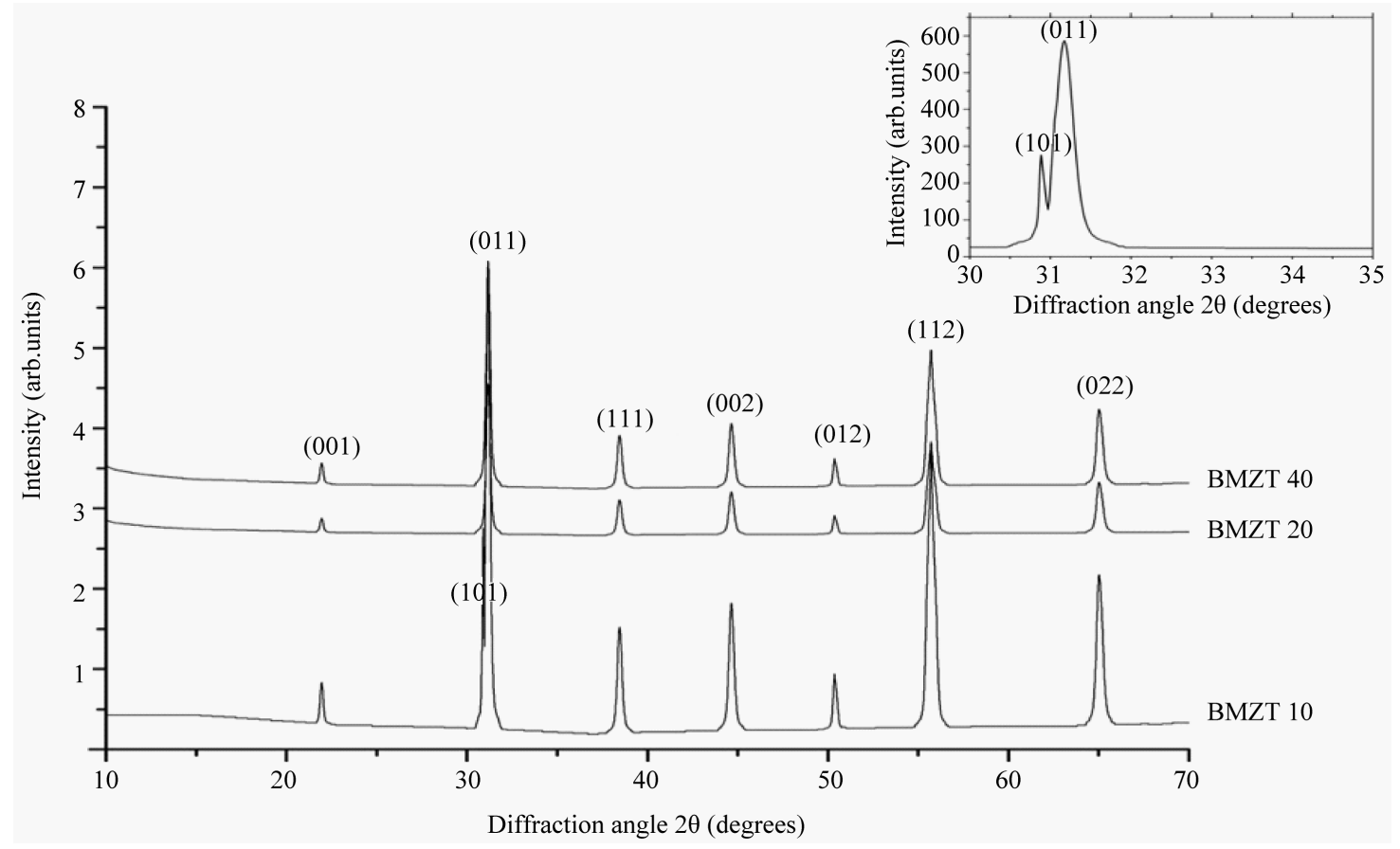

Figure 1. X-ray diffractograms of BMZT 10, BMZT 20 and BMZT 40 samples..

the samples are having single perovskite structure. $\mathrm{BaTiO}_{3}$ (BTO) has the tetragonal structure at room temperature. The ionic radii of $\mathrm{Ba}^{2+}$ and $\mathrm{Ti}^{4+}$ are $1.35 \AA$ and $0.605 \AA$ respectively. If we doped $\mathrm{BTO}$ with $\mathrm{Mg}^{2+}$ and $\mathrm{Zr}^{4+}$ whose ionic radii are both $0.72 \AA \mathrm{Mg}$ occupies A site and Zr occupies B site of BTO. The pure BMZT single phased tertagoganl structure when the $\mathrm{Mg}$ content is $<1.5 \%$ at- $\%$ (9) and $\mathrm{Zr}$ is $0.1 \%$, if $\mathrm{Zr}$ content is $<0.42 \%$ at- $\%$ (10) the sample is changes into the cubic structure. By doping with $\mathrm{Zr}$ the diffraction angles are shifted towards the lower angle side indicating the increase in lattice parameters due to the incorporation of smaller content of $\mathrm{Zr}$ in place of Ba. In Figure 1 BMZT 10 sample possesses the tetragonal structure and BMZT 20 and BMZT 40 samples posses the cubic structure.

\subsection{Microstructural Analysis}

Figure 2 shows The SEM micrographs BMZT 10, BMZT 20 and BMZT 40 samples. It is found that the average grain size of samples are $\sim 1.00, \sim 1.10$ and $\sim 1.66 \mu \mathrm{m}$ increased as the $\mathrm{Zr}$ content increases from $10 \%$ to $40 \%$. This increase is in agreement with our XRD pattern. Moreover the surface observation shows a good density of grains with some porosity.

\subsection{Dielectric Properties}

\subsubsection{Temperature Dependence Dielectric Properties}

Figure 3 shows the temperature dependence of the dielectric constant and loss of $\mathrm{Zr}$ doped BMZT samples measured at $1 \mathrm{MHz}$. The figure shows, the value of dielectric constant increases gradually to a maximum value $\left(\varepsilon_{m}\right)$ with increase in temperature up to transition temperature and then decreases indicating a phase transition. It is also found that the Curie temperature $\mathrm{T}_{\mathrm{c}}$ of BMZT samples with $\mathrm{Zr}$ dopant of $(0.10,0.20,0.40)$ corresponding to the maximum dielectric constant is 373,323 and 180 respectively. The results indicates that the curie temperature of BMZT decreased may be due to Ti ions replaced by $\mathrm{Zr}$ ions and $\mathrm{Zr}$ ionic radius is little more, it can increase the grain size and exactly not joining the $\mathrm{Zr}$ atoms in $\mathrm{Ti}$ sites, due to the $\mathrm{Zr}$ ions conducts the little current then the dielectric constant and curie temperature both may be decreased. According to Figures 3(a)-(c) the peak value of the dielectric constant of BMZT samples with the Zr dopant of $(0.10,0.20,0.40)$ is 1406,1040 and 563 respectively. The result indicates that the peak value of dielectric constant for low doped sample is the maximum and the peak value decreases with $\mathrm{Zr}$ content. 


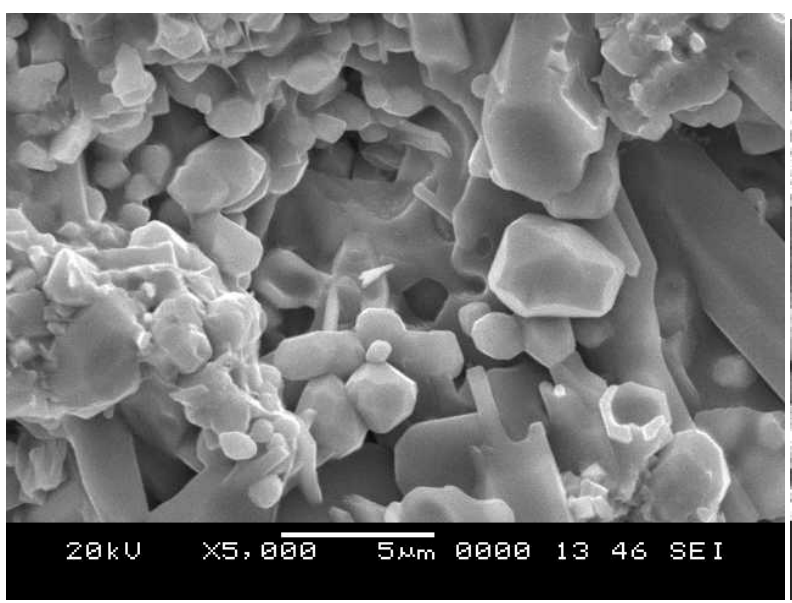

(a)

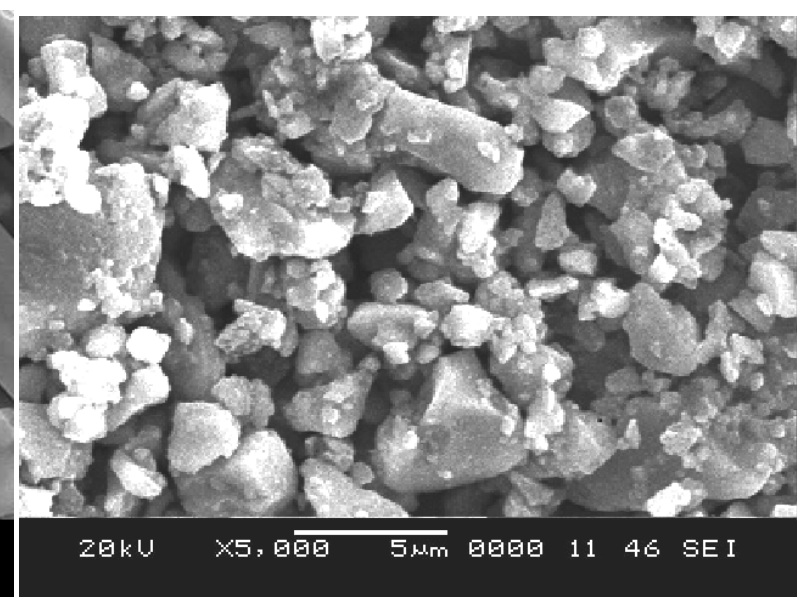

(b)

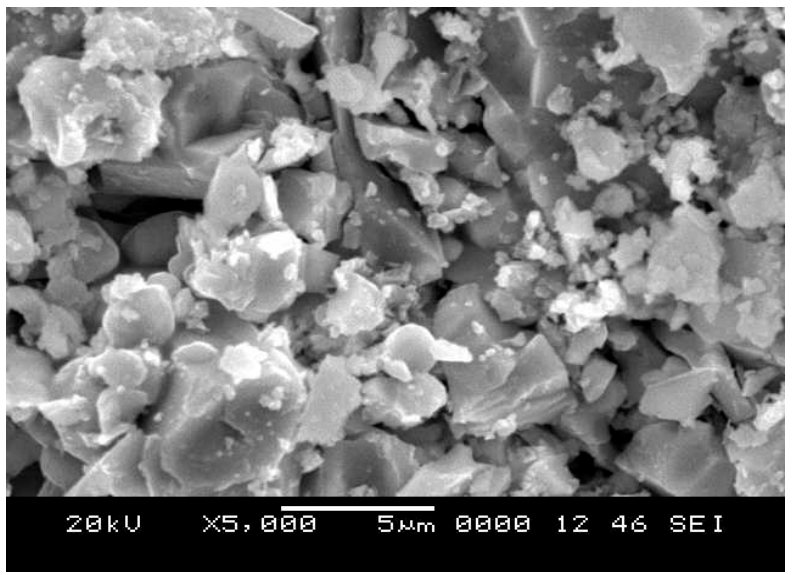

(c)

Figure 2. SEM micrograph of (a) BMZT 10, (b) BMZT 20, (c) BMZT 40 samples.

In Figure 3(c) shows that the dielectric loss initially increases with temperature reaches maximum. Further increase in temperature loss is decreased but for BMZT samples of $(0.10,0.20)$ it is at lower temperature little bit high value of loss due to the presence of all types of polarisation and may be due to the contribution of finite resistivity of the materials. Further increase in temperature loss decreases minimum and further increasing temperature loss also increased.

\subsubsection{Frequency Dependence Dielectric Properties}

As shown in Figure 4(a) it is found that the dielectric constant of BMZT $(0.10,0.20,0.40)$ decreased rapidly at low frequencies. At very high frequencies dielectric constant is very low and it maintains constant value. It may be due to there must be defects with opposite charges (dipoles) to preserve charge neutrality. Theses dipoles could be oriented to align the direction of the applied electric field. When the frequency increases, the dipoles do not catch up with the change of the electric field to complete polarisation so that the dielectric constant decreases.

In the Figure 4(b) the dielectric losses were a combined result of electrical conduction and orientational polarisation of the matter. The energy losses, which occur in dielectrics due to dc conductivity and dipole relaxation. The loss factor of a dielectric material is a useful indicator of the energy loss as heat.

\section{Conclusion}

Perovskite types $\left(\mathrm{Ba}_{0.9} \mathrm{Mg}_{1.0}\right)\left(\mathrm{Zr}_{\mathrm{x}} \mathrm{Ti}_{1-\mathrm{x}}\right) \mathrm{O}_{3}$ (with $\mathrm{x}=0.10,0.20,0.40$ ) ceramics have prepared through solid state reaction route. The XRD study at room temperature suggests that the composition of BMZT 10 has single phase 


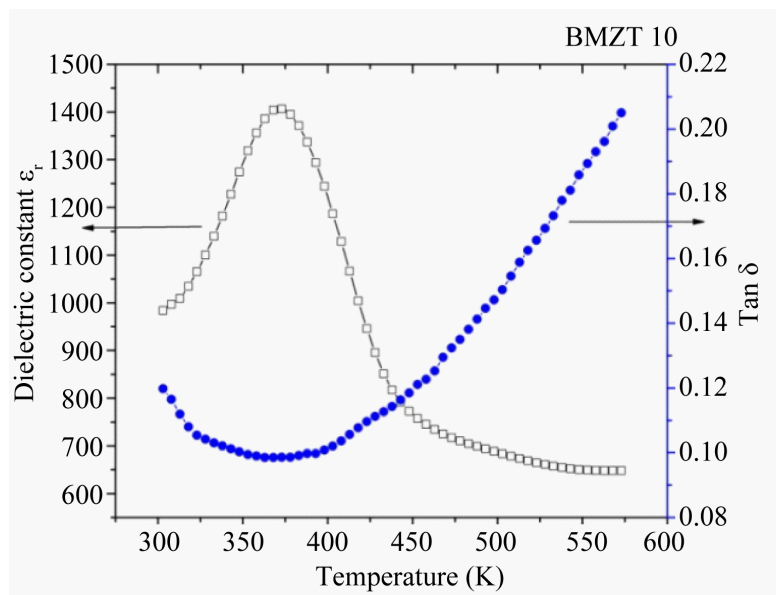

(a)

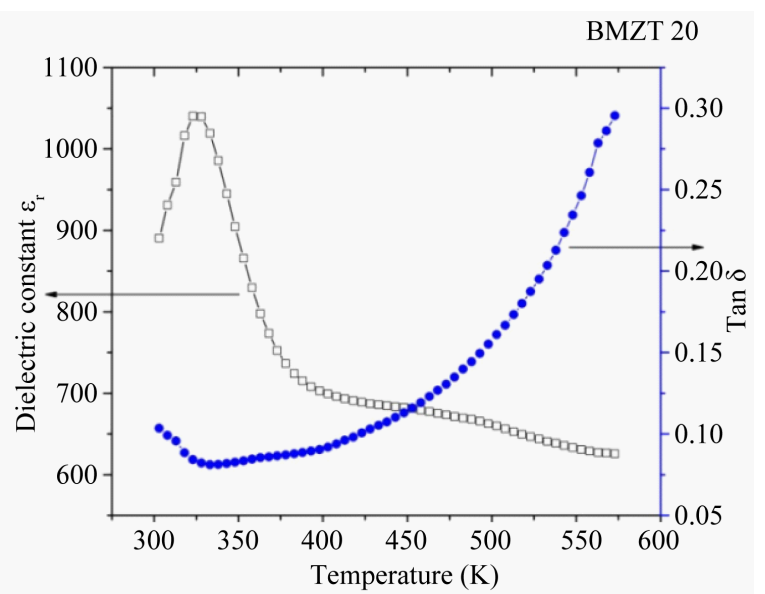

(b)

BMZT 20

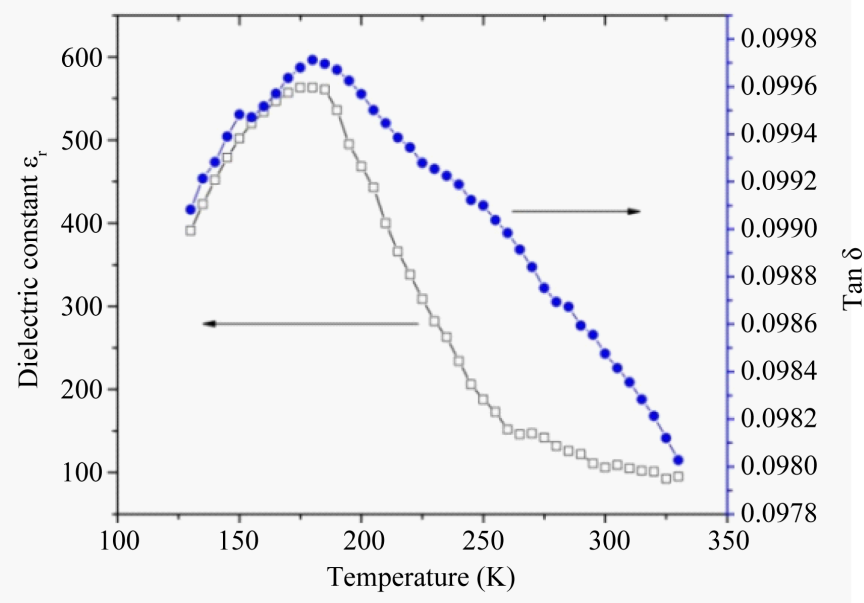

(c)

Figure 3. Temperature dependence of Dielectric constant and Dielectric loss of (a) BMZT 10, (b) BMZT 20, (c) BMZT 40 samples.

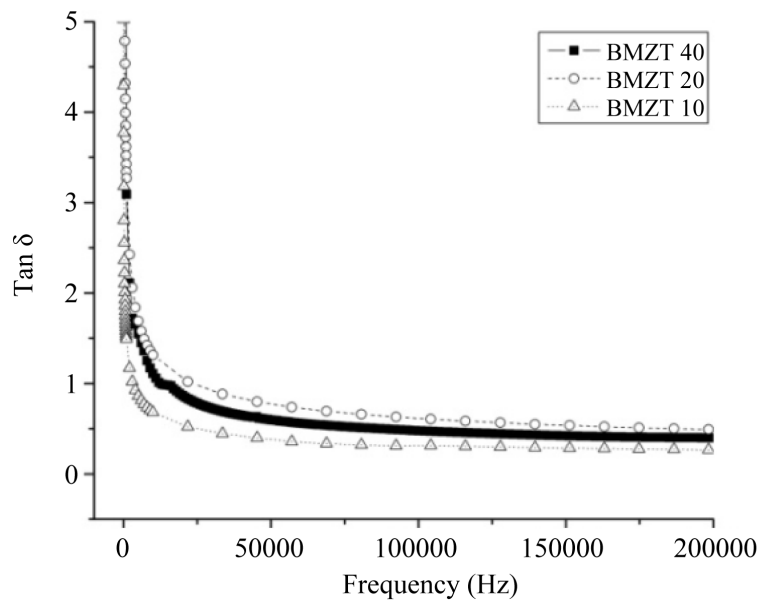

(a)

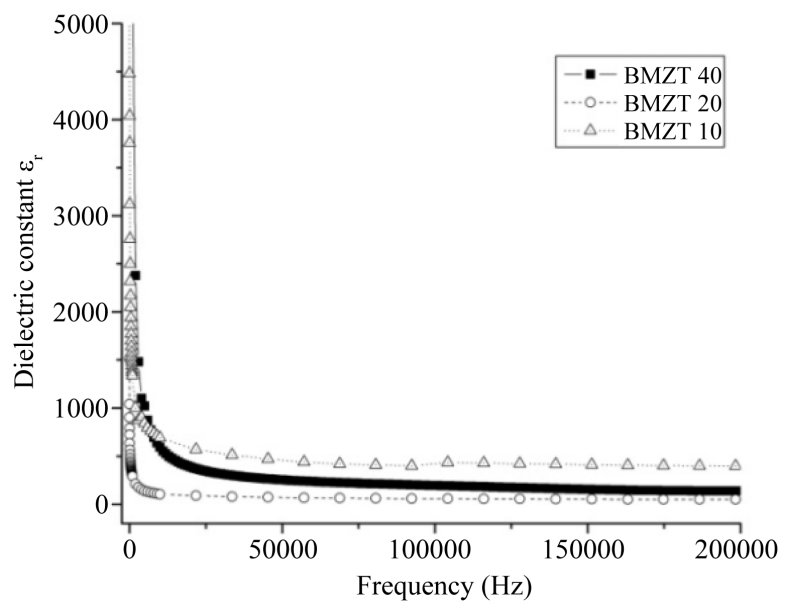

(b)

Figure 4. Frequency dependence of (a) Dielectric constant, (b) Dielectric loss of BMZT 10, BMZT 20 and BMZT 40 samples. 
tetragonal and BMZT 20, BMZT 40 cubic symmetry with space group pm-3m. The dielectric study reveals that the materials undergo BMZT 20, BMZT 40 a diffuse type ferroelectric phase transition. The transition temperature decreased with $\mathrm{Zr}$ content and the maximum dielectric constant also decreased with Zr content.

\section{References}

[1] Takenaka, T. and Nagata, H. (2005) Current Status and Prospects of Lead-Free Piezoelectric Ceramics. Journal of the European Ceramic Society, 25, 2693-2700. http://dx.doi.org/10.1016/j.jeurceramsoc.2005.03.125

[2] Saito, Y., Takao, H., Tani, T., et al. (2004) Lead-Free Piezoceramics. Nature, 432, 84-87. http://dx.doi.org/10.1038/nature03028

[3] Dixit, A., Majumder, S.B., Katiyar, R.S. and Bhalla, A.S. (2003) Relaxor Behavior in Sol-Gel-Derived $\mathrm{BaZr}_{(0.40)} \mathrm{Ti}_{(0.60)} \mathrm{O}_{3}$ Thin Films. Applied Physics Letters, 82, 2679. http://dx.doi.org/10.1063/1.1568166

[4] Dobal, P.S., Katiyar, R.S. and Raman, J. (2002) Studies on Ferroelectric Perovskites and Bi-Layered Compounds Using Micro-Raman Spectroscopy. Journal of Raman Spectroscopy, 33, 405-423. http://dx.doi.org/10.1002/jrs.876

[5] Dixit, A., Majumder, S.B., Savvinov, A., Katiyar, R.S., Guo, R. and Bhalla, A.S. (2002) Investigations on the Sol-GelDerived Barium Zirconium Titanate Thin Films. Materials Letters, 56, 933-940. http://dx.doi.org/10.1016/S0167-577X(02)00640-7

[6] Paik, D.S., Park, S.E., Wada, S., Liu, S.F. and Shrout, T.R. (1999) E-Field Induced Phase Transition in <001>Oriented Rhombohedral 0.92Pb( $\left.\mathrm{Zn}_{1 / 3} \mathrm{Nb}_{2 / 3}\right) \mathrm{O}_{3}-0.08 \mathrm{PbTiO}_{3}$ Crystals. Journal of Applied Physics, 85, 1080. http://dx.doi.org/10.1063/1.369252

[7] Yu, Z., Ang, C., Guo, R. and Bhalla, A.S. (2002) Dielectric Properties and High Tunability of Ba(Ti $\left.\mathrm{Ti}_{0.7} \mathrm{Zr}_{0.3}\right) \mathrm{O}_{3} \mathrm{Ceram-}$ ics under dc Electric Field. Applied Physics Letters, 81, 1285. http://dx.doi.org/10.1063/1.1498496

[8] Dash, S.K., Kant, S., Dalai, B., Swain, M.D. and Swain, B.B. (2014) Characterization and Dielectric Properties of Barium Zirconium Titanate Prepared by Solid State Reaction and High Energy Ball Milling Processes. Journal of Applied Physics, 88, 129-135.

[9] Badapanda, T., Cavalcante, L.S., da Luz Jr., G.E., Batista, N.C., Anwar, S. and Longo, E. (2013) Effect of Yttrium Doping in Barium Zirconium Titanate Ceramics: A Structural, Impedance, and Modulus Spectroscopy Study. Metallurgical and Materials Transactions A, 44, 4296.

[10] Chen, T., Zhang, T., Zhou, J.F., Zhang, J.W., Liu, Y.H. and Wang, G.C. (2012) Piezoelectric Properties of $\left[\left(\mathrm{K}_{1-\mathrm{x}} \mathrm{Na}_{\mathrm{x}}\right) 0.95 \mathrm{Li}_{0.05}\right] 0.985 \mathrm{Ca}_{0.015}\left(\mathrm{Nb}_{0.95} \mathrm{Sb}_{0.05}\right) 0.985 \mathrm{Ti}_{0.015} \mathrm{O}_{3}$ Lead-Free Ceramics. Indian Journal of Physics, 86, 443-446. http://dx.doi.org/10.1007/s12648-012-0087-1

[11] Mitic, V.V., Nikolic, Z.S., Pavlovic, V.B., Paunovic, V., Miljkovic, M., Jordovic, B. and Zivkovic, L. (2010) Influence of Rare-Earth Dopants on Barium Titanate Ceramics Microstructure and Corresponding Electrical Properties. Journal of the American Ceramic Society, 93, 132-137. http://dx.doi.org/10.1111/j.1551-2916.2009.03309.x

[12] Jung, W.S., Kim, J.H., Kim, H.T. and Yoon, D.H. (2010) Effect of Temperature Schedule on the Particle Size of Barium Titanate during Solid-State Reaction. Materials Letters, 64, 170-172. http://dx.doi.org/10.1016/j.matlet.2009.10.035

[13] Cao, W.Q., Xiong, J.W. and Sun, J.P. (2007) Dielectric Behavior of Nb-Doped $\mathrm{Ba}\left(\mathrm{Zr}_{\mathrm{x}} \mathrm{Ti}_{1-\mathrm{x}}\right) \mathrm{O}_{3}$. Materials Chemistry and Physics, 106, 338-342. http://dx.doi.org/10.1016/j.matchemphys.2007.06.017

[14] Singh, S.V., Thakur, A.N., Singh, O.P., Kumar, S.C. and Ahmad, A. (2009) Dielectric Properties of $\mathrm{PbSrWO}_{4}$ and $\mathrm{PbBaWO}_{4}$ Compounds. Indian Journal of Physics, 83, 375-381. http://dx.doi.org/10.1007/s12648-009-0125-9

[15] Chen, T., Wang, H.L., Zhang, T., Zhou, J.F., Zhang, J.W., Liu, Y.H. and Wang, G.C. (2013) Piezoelectric Properties of $\mathrm{La}$ and $\mathrm{Nb}$ Co-Modified $\mathrm{Bi}_{4} \mathrm{Ti}_{3} \mathrm{O}_{12}$ High-Temperature Ceramics. Indian Journal of Physics, 87, 629-631. http://dx.doi.org/10.1007/s12648-013-0278-4

[16] Parkash, O., Kumar, D., Dwivedi, R.K., Srivastava, K.K., Singh, P. and Singh, S. (2007) Effect of Simultaneous Substitution of La and Mn on Dielectric Behavior of Barium Titanate Ceramic. Journal of Materials Science, 42, 5490-5496. http://dx.doi.org/10.1007/s10853-006-0985-8

[17] Langhammer, H.T., Müller, T., Böttcher, R. and Abicht, H.P. (2008) Structural and Optical Properties of ChromiumDoped Hexagonal Barium Titanate Ceramics. Journal of Physics: Condensed Matter, 20, Article ID: 085206. http://dx.doi.org/10.1088/0953-8984/20/8/085206

[18] Lu, D.Y., Toda, M. and Sugano, M. (2006) High-Permittivity Double Rare-Earth-Doped Barium Titanate Ceramics with Diffuse Phase Transition. Journal of the American Ceramic Society, 89, 3112-3123. http://dx.doi.org/10.1111/j.1551-2916.2006.00893.x

[19] Chen, Z.W. and Chu, J.Q. (2008) Piezoelectric and Dielectric Properties of $\mathrm{Bi}_{0.5}\left(\mathrm{Na}_{0.84} \mathrm{~K}_{0.16}\right)_{0.5} \mathrm{TiO}_{3}-\mathrm{Ba}_{(}\left(\mathrm{Zr}_{0.04} \mathrm{Ti}_{0.96}\right) \mathrm{O}_{3}$ Lead Free Piezoelectric Ceramics. Advances in Applied Ceramics, 107, 222-226. 
http://dx.doi.org/10.1179/174367608X263403

[20] Fu, C.L., Cai, W., Chen, H.W., Feng, S.C., Pan, F.S. and Yang, C.R. (2008) Voltage Tunable $\mathrm{Ba}_{0.6} \mathrm{Sr}_{0.4} \mathrm{TiO}_{3} \mathrm{Thin} \mathrm{Films}$ and Coplanar Phase Shifters. Thin Solid Films, 516, 5258-5261. http://dx.doi.org/10.1016/j.tsf.2007.07.059

[21] Cai, W., Fu, C.L., Gao, J.C. and Chen, H.Q. (2009) Effects of Grain Size on Domain Structure and Ferroelectric Properties of Barium Zirconate Titanate Ceramics. Journal of Alloys and Compounds, 480, 870-873. http://dx.doi.org/10.1016/j.jallcom.2009.02.049

[22] Du, F.T., Yu, P.F., Cui, B., Cheng, H.O. and Chang, Z.G. (2009) Preparation and Characterization of Monodisperse Ag Nanoparticles Doped Barium Titanate Ceramics. Journal of Alloys and Compounds, 478, 620-623. http://dx.doi.org/10.1016/j.jallcom.2008.11.099

[23] Yuan, Y., Zhang, S.R., Zhou, X.H. and Tang, B. (2009) Effects of $\mathrm{Nb}_{2} \mathrm{O}_{5}$ Doping on the Microstructure and the Dielectric Temperature Characteristics of Barium Titanate Ceramics. Journal of Materials Science, 44, 3751-3757. http://dx.doi.org/10.1007/s10853-009-3502-z

[24] Xiao, S.X. and Yan, X.P. (2009) Preparation and Characterization of Si-Doped Barium Titanate Nanopowders and Ceramics. Microelectronic Engineering, 86, 387-391. http://dx.doi.org/10.1016/j.mee.2008.11.042

[25] Rath, M.K., Pradhan, G.K., Pandey, B., Verma, H.C., Roul, B.K. and Anand, S. (2008) Synthesis, Characterization and Dielectric Properties of Europium-Doped Barium Titanate Nanopowders. Materials Letters, 62, 2136-2139. http://dx.doi.org/10.1016/j.matlet.2007.11.033

[26] Gulwade, D. and Gopalan, P. (2008) Diffuse Phase Transition in La and Ga Doped Barium Titanate. Solid State Communications, 146, 340-344. http://dx.doi.org/10.1016/j.ssc.2008.02.018

[27] Unruan, M., Sareein, T., Tangsritrakul, J., Prasetpalichatr, S., Ngamjarurojana, A., Anata, S. and Yimnirun, R. (2008) Changes in Dielectric and Ferroelectric Properties of $\mathrm{Fe}^{3+} / \mathrm{Nb}^{5+}$ Hybrid-Doped Barium Titanate Ceramics under Compressive Stress. Journal of Applied Physics, 104, Article ID: 124102. http://dx.doi.org/10.1063/1.3042228

[28] Yaseen, H., Baltianski, S. and Tsur, Y. (2006) Effect of Incorporating Method of Niobium on the Properties of Doped Barium Titanate Ceramics. Journal of the American Ceramic Society, 89, 1584-1589. http://dx.doi.org/10.1111/j.1551-2916.2006.00966.X

[29] Cha, S.H. and Han, Y.H. (2006) Effects of Mn Doping on Dielectric Properties of Mg-Doped BaTiO 3 . Journal of Applied Physics, 100, Article ID: 104102. http://dx.doi.org/10.1063/1.2386924

[30] Shen, Z.J., Chen, W.P., Qi, J.Q., Wang, Y., Chan, H.L.W., Chen, Y. and Jiang, X.P. (2009) Dielectric Properties of

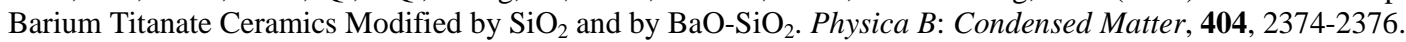
http://dx.doi.org/10.1016/j.physb.2009.04.039

[31] Kirianov, A., Hagiwara, T., Kishi, H. and Ohsato, H. (2002) Effect of Ho/Mg Ratio on Formation of Core-Shell Structure in $\mathrm{BaTiO}_{3}$ and on Dielectric Properties of $\mathrm{BaTiO}_{3}$ Ceramics. Japanese Journal of Applied Physics, 41, 6934-6937. http://dx.doi.org/10.1143/JJAP.41.6934

[32] Wang, S., Zhang, S.R., Zhou, X.H., Li, B. and Chen, Z. (2005) Effect of Sintering Atmospheres on the Microstructure and Dielectric Properties of $\mathrm{Yb} / \mathrm{Mg}$ Co-Doped $\mathrm{BaTiO}_{3}$ Ceramics. Materials Letters, 59, 2457-2460. http://dx.doi.org/10.1016/j.matlet.2005.03.016

[33] Rout, S.K., Sinha, E. and Panigrahi, S. (2007) Dielectric Properties and Diffuse Phase Transition in $\mathrm{Ba}_{1-x} \mathrm{Mg}_{\mathrm{x}} \mathrm{Ti}_{0.6} \mathrm{Zr}_{0.4^{-}}$ $\mathrm{O}_{3}$ Solid Solutions. Materials Chemistry and Physics, 101, 428-432. http://dx.doi.org/10.1016/j.matchemphys.2006.08.002

[34] Henning, D., Schnell, A. and Simon, G. (1982) Diffuse Ferroelectric Phase Transitions in $\mathrm{Ba}\left(\mathrm{Ti}_{1-\mathrm{y}} \mathrm{Zr}_{\mathrm{y}}\right) \mathrm{O}_{3}$ Ceramics. Journal of the American Ceramic Society, 65, 539-544. http://dx.doi.org/10.1111/j.1151-2916.1982.tb10778.x

[35] Yu, Z., Guo, R. and Bhalla, A.S. (2000) Dielectric Behavior of $\mathrm{Ba}\left(\mathrm{Ti}_{1-\mathrm{x}} \mathrm{Zr}_{\mathrm{x}}\right) \mathrm{O}_{3}$ Single Crystals. Journal of Applied Physics, 88, 410. http://dx.doi.org/10.1063/1.373674 